\title{
Synthesis and Characterization of Titanium (iv) Oxide Loaded with Silver Nano Particles Thin Films
}

\author{
Sunday Wilson Balogun 1, *, Afolabi Bola Abdulhamid ${ }^{3}$, Yekini Kolawole Sanusi ${ }^{1,2}$, \\ Adedokun Oluwaseun ${ }^{2}$ \\ ${ }^{1}$ Department of Physics and Materials Science, Kwara State University Malete, Ilorin, Nigeria \\ ${ }^{2}$ Department of Pure and Applied Physics, Ladoke Akintola University of Technology, Ogbomoso, Nigeria \\ ${ }^{3}$ Department of Physics, School of Science, Kwara State College of Education, Ilorin, Nigeria
}

\section{Email address:}

sbalogun94@gmail.com (S. W. Balogun), afolabibola383@gmail.com (A. B. Afolabi), sanusiyk33@gmail.com (Y. K. Sanusi), oadedokun@lautech.edu.ng (A. Oluwaseun)

${ }^{*}$ Corresponding author

\section{To cite this article:}

Sunday Wilson Balogun, Afolabi Bola Abdulhamid, Yekini Kolawole Sanusi, Adedokun Oluwaseun. Synthesis and Characterization of Titanium (iv) Oxide Loaded with Silver Nano Particles Thin Films. American Journal of Nano Research and Applications.

Vol. 7, No. 1, 2019, pp. 1-5. doi: 10.11648/j.nano.20190701.11

Received: February 16, 2019; Accepted: March 26, 2019; Published: April 22, 2019

\begin{abstract}
This research investigates effect of annealing temperature on the optical properties of titanium dioxide loaded with silver nanoparticles $\left(\mathrm{TiO}_{2}\right.$ : AgNPs) thin films deposited on glass substrate by spin-coating technique. Silver nanoparticles was prepared using laguminosae-paplionodeae extracts as a reducing agent for silver nitrate and commercially available titanium (iv) oxide was used. Deposition of $\mathrm{TiO}_{2}: \mathrm{AgNPs}$ blend solution was done in different volume ratio. The blend solution volume ratio of (1:0.2) was deposited at 7 different thicknesses with different speed of revolution per minutes (rpm) for 30 seconds. Annealing of 16 samples deposited at $1000 \mathrm{rpm}$ on the glass substrate was carried out at temperature range of $50^{\circ} \mathrm{C}$ to $425^{\circ} \mathrm{C}$ with $10^{\circ} \mathrm{C}$ interval in a tubular furnance. It is observed from the results that the peak absorption of photon energy occurred at $375^{\circ} \mathrm{C}$ in the visible range of the wavelength spectrum. Optimal thickness for peak absorbance of the $\mathrm{TiO}_{2}: \mathrm{AgNPs}$ blend layer occurred at $115 \mathrm{~nm}$ in the visible spectrum and at the corresponding spin speed of $1000 \mathrm{rpm}$. Optimized fabrication process with blend layer thickness of $115 \mathrm{~nm}$ yielded the best absorbance at annealed temperature of $375^{\circ} \mathrm{C}$ in the visible spectrum. The volume ratio of (1:0.2) gave the peak absorption at $0.75 \mathrm{a} \mathrm{u}$. The band gap energy of the blend thin film is 3.58 $\mathrm{eV}$ at $375^{\circ} \mathrm{C}$ in the visible range of wavelength spectrum. It is revealed from the result that the light absorption, broadened absorption spectral range and thermal stability of titanium (iv) oxide film could be enhanced using silver nanoparticles. The results can be therefore used as a guideline for improving the design and fabrication of organic solar cells.
\end{abstract}

Keywords: Organic Thin Film, Silver Nanoparticles, Titanium Dioxide, Annealing, Blend AgNPs:TiO 2 , Optical Properties

\section{Introduction}

The demand for clean energy sources has increased, leading to a rapid growth in the field of research and development of solar energy. The creation of nanoscale materials for advanced structures has led to a growing research interest in the area of photovoltaic energy conversion using photovoltaics devices Today's solar cells are simply not efficient enough and are currently too expensive to manufacture for large-scale electricity generation. However, potential advancements in nanotechnology may open the door to the production of cheaper and slightly more efficient solar cells. Solar cells are devices which convert the light into electrical energy [1]. Solar cells can be fabricated using organic, inorganic or hybrid materials and are divided into three different generations [2]. The First generation consists of crystalline semiconductor wafers with a thickness of 200-300 $\mu \mathrm{m}$. The Second-generation solar cells are based on thin film technology having thickness, usually in the range of 1-2 $\mu \mathrm{m}$. The- Third generation solar cells are under research process, to increase the efficiency with the help of second generation 
solar cells. A new method has evolved in recent times for increasing the light absorption i.e., the use of nanoparticles with size ranging between 10-1000 nm [3-4]. Nanotechnology is a new branch of technology that studies different materials at a nanometric scale. It partakes in the design, production, and use of chemical structures with extremely small dimensions, which have been applied in areas such as materials science, engineering, and electronics. The nano structured metal oxides have received increasing consideration due to their unique physical and chemical properties and in particular, the functional metal oxides have emerged as strong candidates for variety of applications [511]. Silver nanoparticles have unique optical, electrical, and thermal properties and are being incorporated into products that range from photovoltaics to biological and chemical sensors [12-16]. Examples include conductive inks, pastes and fillers which utilize silver nanoparticles for their high electrical conductivity, stability, and low sintering temperatures. Nanomaterials are used in many different industrial fields such as microelectronics, micro-machineries, optics, molecular diagnostics, photonic devices, and composite materials [17-23]. This research investigates effect of annealing temperature on the optical properties of titanium dioxide loaded with silver nanoparticles $\left(\mathrm{TiO}_{2}\right.$ : AgNPs $)$ thin films deposited on glass substrate by spin-coating technique. It is revealed from the result that the light absorption, broadened absorption spectral range and thermal stability of titanium (iv) oxide film could be enhanced using silver nanoparticles. The results can be therefore used as a guideline for improving the design and fabrication of organic solar cells.

\section{Materials and Methods}

\subsection{Materials}

The materials used for the research are Titanium (IV) oxide Nano powder $(<.35 \mathrm{~nm}), 97 \%$. supplied by Sigma Aldrich. Silver nitrate was purchased locally.

\subsection{Methods}

The following experimental procedures were carried out.

\subsubsection{Substrate Preparation}

Clean rectangular glass slides of dimension $25.4 \mathrm{~mm}$ by $76.2 \mathrm{~mm}$ were used as substrates. The glass substrates were washed with detergent solution for 10 to 15 minutes in ultrasonic sonicator and rinsed in distilled water for 15 minutes at $30^{\circ} \mathrm{C}$. The substrate was cleaned with Isopropanol alcohol [IPA] in ultrasonic bath for 15 minutes at $30^{\circ} \mathrm{C}$ and dried in a stream of nitrogen gas $\left(\mathrm{N}_{2}\right)$.

\subsubsection{Sample Solution Preparation}

\section{i Titanium Dioxide $\left(\mathrm{TiO}_{2}\right)$ Preparation}

$25 \mathrm{ml}$ Ethanol solvent was added into $3 \mathrm{~g}$ of $\mathrm{TiO}_{2}$ powder from Sigma Aldrich. The solution then underwent ageing process for 3 hours upon sonication at room temperature without heat to allow homogeneous mixture and $\mathrm{TiO}_{2}$ powder to fully dilute into solvent. Ethanol was chosen as a solvent because it has no characteristic absorption and emission in the visible range.

ii Aqueous Silver Nitrate Solution Preparation

$0.168 \mathrm{~g}$ of Silver nitrate was dissolved in $100 \mathrm{ml}$ distilled water which gives colorless clear solution.

iii Silver Nanoparticles (AgNPs) Preparation

3 grams of Agunmaniye (Yoruba name), laguminosaepaplionodeae (Botanical name), Glincidiasepium (English name). The leaves were thoroughly washed, rinsed and cut into smaller piece. Thereafter, the smaller pieces of leaves were immersed in $300 \mathrm{ml}$ of boiling distilled water for 30 minutes and filtered. The obtained extract was dripped into $100 \mathrm{ml}$ of $0.01 \mathrm{M}$ of aqueous silver nitrate solution with constant gentle stirring for homogenous mixture. The yellowish brown appearance of the product indicated the formation of the silver nanoparticles. It was then stored in brown bottle and shield from the ray of light.

iv Blend Solution Preparation

The blend solution ( $\left.\mathrm{TiO}_{2}: \mathrm{AgNPs}\right)$ was done by mixing $\mathrm{TiO}_{2}$ solution with AgNPs solution at different volume ratio $(1: 1,1: 0.8,1: 0.6,1: 0.4,1: 0.2) \mathrm{ml}$ and stirred using magnetic stirrer for homogeneous mixture.

\subsubsection{Deposition}

Deposition of $\mathrm{TiO}_{2}$ :AgNPs blend solution on the cleaned glass substrate was done at 5 different volume ratio $(1: 1,1$ : $0.8,1: 0.6,1: 0.4,1: 0.2) \mathrm{ml}$ using spin -coater (laurel WS$650 \mathrm{~Hz}-23 \mathrm{NPP})$. The blend solution with volume ratio of (1:0.2) ml with optimized absorption was used to deposit (7) film of layer thicknesses of $30 \mathrm{~nm},<35 \mathrm{~nm}, 35 \mathrm{~nm}, 87 \mathrm{~nm}$, $98 \mathrm{~nm}, 115 \mathrm{~nm}$, and $146 \mathrm{~nm}$ corresponding to spin coating speeds of $4000 \mathrm{rpm}, 3000 \mathrm{rpm}, 2000 \mathrm{rpm}, 1500 \mathrm{rpm}$, $1250 \mathrm{rpm}, 1000 \mathrm{rpm}$, and $750 \mathrm{rpm}$, respectively for 30 seconds. Depending on the concentration and the speed of the spin coater, the desirable thickness of the sample was obtained. At $1000 \mathrm{rpm}$ with corresponding thickness of $115 \mathrm{~nm}$, has best absorption value. The optimum absorbance at $1000 \mathrm{rpm}$ was used for the preparation of the 17 samples film fabrication process. 17 samples deposited at $1000 \mathrm{rpm}$ served as annealed films (16) and control.

\subsubsection{Annealing}

Annealing of the samples deposited was carried out at temperature ranges of $50^{\circ} \mathrm{C}$ to $425^{\circ} \mathrm{C}$ with $10^{\circ} \mathrm{C}$ interval in a carbolite tubular furnance model Srw 21-501042 Type-CT17 for 30 minutes. One sample was used as a reference.

\subsubsection{Characterization}

Characterization studies were carried out on the annealed samples. Absorption spectra were measured using a UV-Vis spectrophotometer (Avantes, Avalight-DH-5-BAL). The absorbance of the samples was determined from transmittance and reflectance values obtained from the spectrophotometer. Observation showed that the peak absorption of photon energy occurred at $375^{\circ} \mathrm{C}$ in the visible spectrum of the wavelength. 
(i) Plots of absorption vs. photon energy in electron volts (eV).

The values of the photon energy were determined from the inverse relationship between energy (in electron volts) and wavelength of the UV-visible spectrum in equation 1 .

$$
\mathrm{E}=\mathrm{hc} / \mathrm{q} \lambda
$$

Where $\mathrm{h}$ is the planck's constant $\left(6.626 \times 10^{-34} \mathrm{~J} . \mathrm{s}\right), \mathrm{C}$ is the speed of light $\left(2.998 \times 10^{8}\right), \lambda$ is the wavelength in nanometres, $\mathrm{q}$ is the electronic charge $\left(1.6 \times 10^{-19} \mathrm{C}\right)$, and $\mathrm{E}$ is the energy in electron volt. 1 electron volt is the energy gained by an electron moving through a potential difference of 1 volt (i.e., $1 \mathrm{eV}=1.6 \times 10^{-19} \mathrm{~J}$ ).

\section{Results and Discussion}

$\mathrm{TiO}_{2}$ loaded with AgNPs prepared at different volume ratio as shown in figure 1 and optimized volume ratio deposited at different spin speeds of 4000rpm, $3000 \mathrm{rpm}, 2000 \mathrm{rpm}$, $1500 \mathrm{rpm}, 1250 \mathrm{rpm}, 1000 \mathrm{rpm}$, and $750 \mathrm{rpm}$ in figure 2 . Heat treatment was carried out on all the samples as shown in figures 3 and 4 . Optimized film thickness for peak absorbance of the $\mathrm{TiO}_{2}$ :AgNPs blend layer occurred at $115 \mathrm{~nm}$ in the visible spectrum and at the corresponding spin speed of $1000 \mathrm{rpm}$. Optimized fabrication process with blend layer thickness of $115 \mathrm{~nm}$ yielded the best absorbance at annealed temperature of $375^{\circ} \mathrm{C}$ in the visible spectrum as shown in figures 3 and 4, the result is in agreement as was reported by [24]. The graph of the plot of absorbance versus photon energy in eV of $\mathrm{TiO}_{2}$ : AgNPs is shown in figures 5 and 6. The band gap energy of the blend thin film is $3.58 \mathrm{eV}$ at $375^{\circ} \mathrm{C}$ in the wavelength range of visible light similar to reported result by [25]. The result also revealed that heat treatment or thermal annealing is a tool that can be used to tune the optical properties of $\mathrm{TiO}_{2}$ : AgNPs blend thin film.

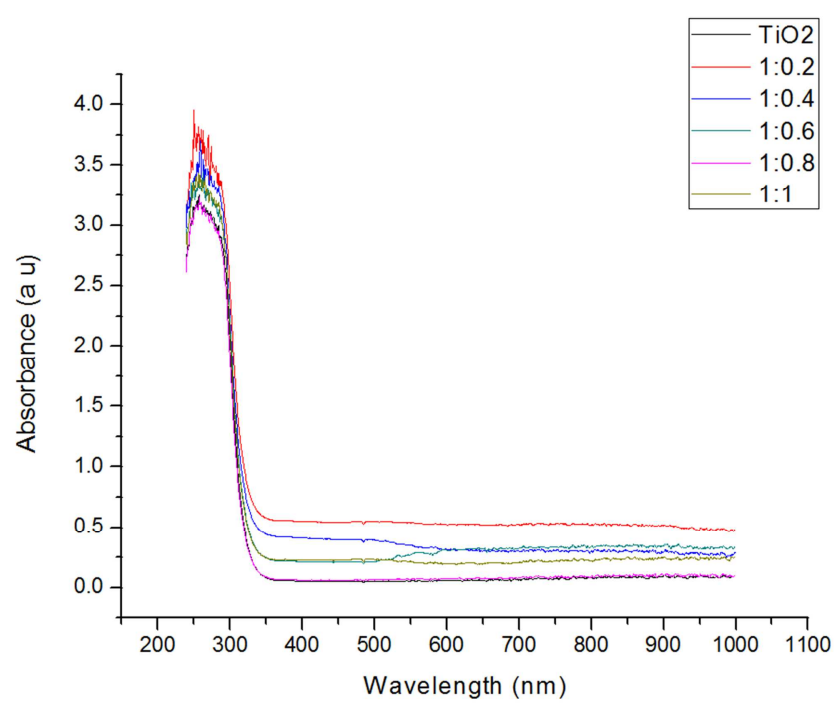

Figure 1. Plot of absorbance of $\mathrm{TiO}_{2}:$ AgNPs vs wavelength blend at different volume ratio.

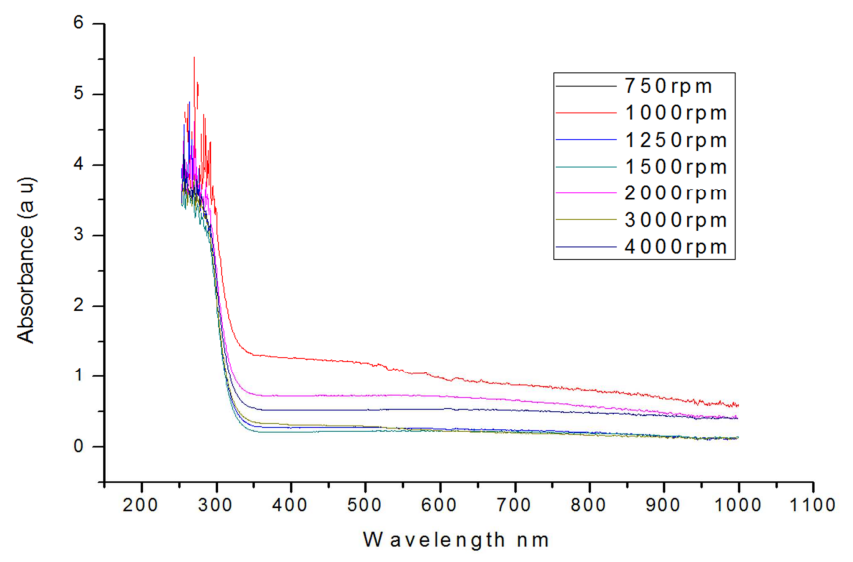

Figure 2. Plot of $\mathrm{TiO}_{2}$ :AgNPs (1:0.2) absorbance vs wavelength at different layer thicknesses.

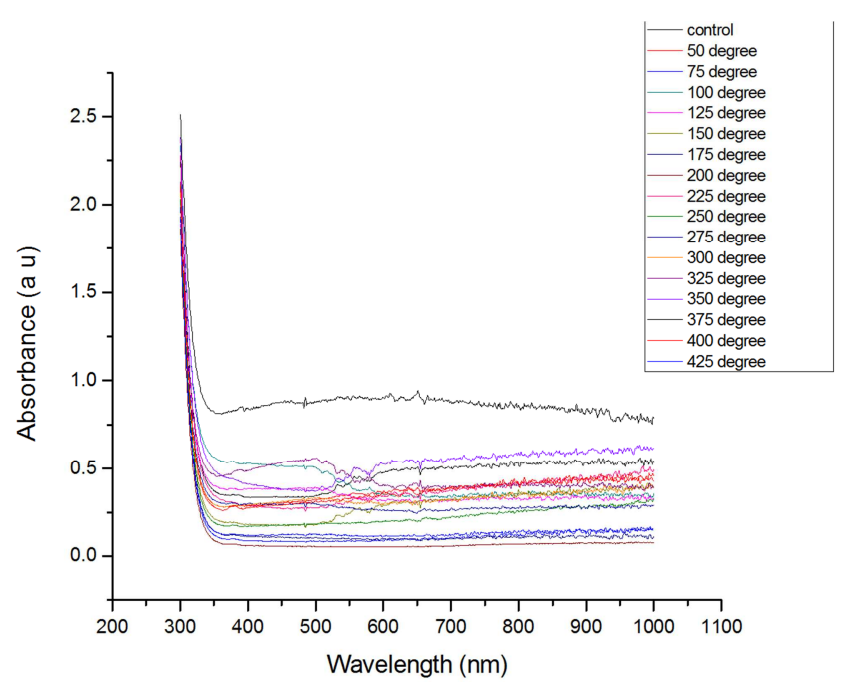

Figure 3. Plot of $\mathrm{TiO}_{2}: A g N P s$ absorbance vs Wavelength at different annealing temperature.

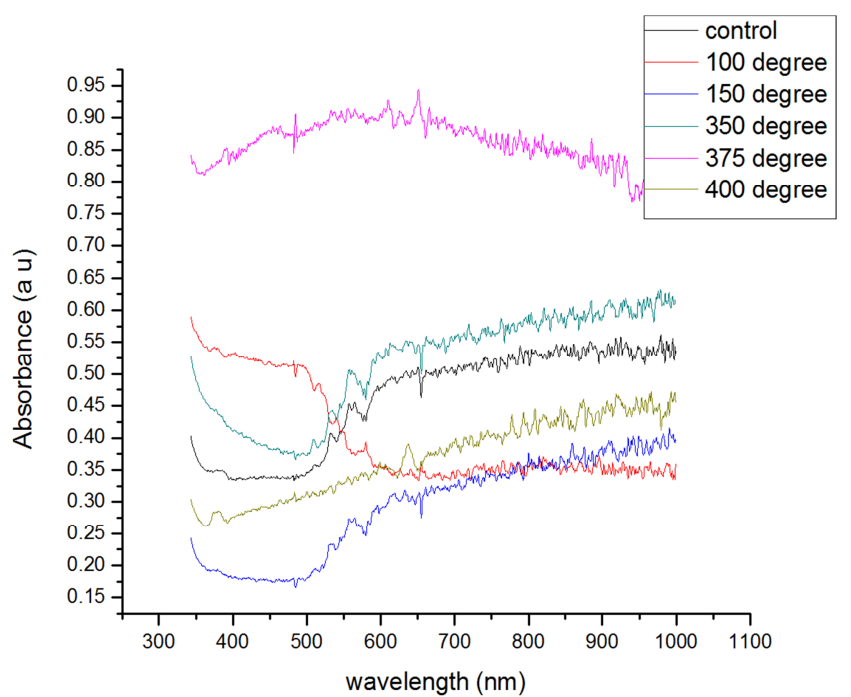

Figure 4. Plot of $\mathrm{TiO}_{2}: \mathrm{AgNPs}$ (1:0.2 volume ratio, at 1000rpm) absorbance vs Wavelength at selected annealing temperature. 


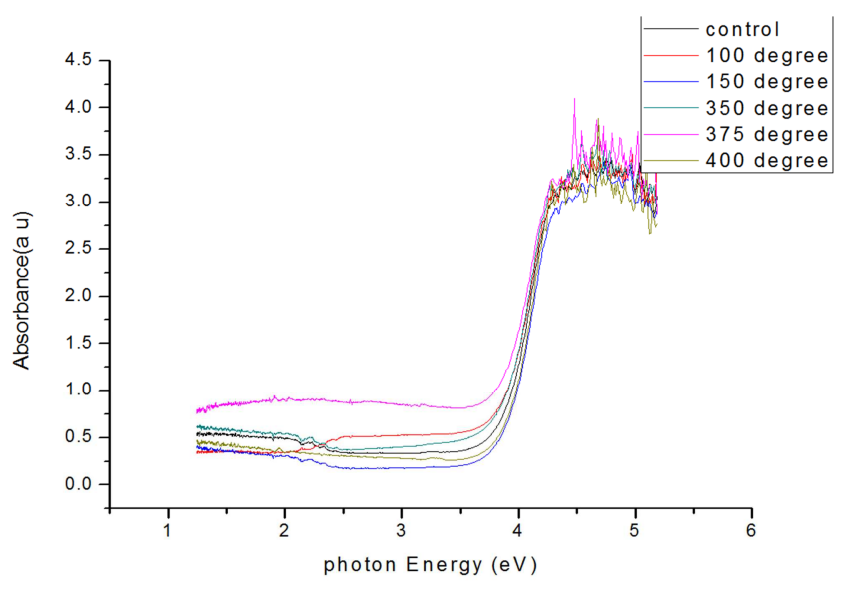

Figure 5. Plot of absorption vs. photon energy in electron volts (eV).

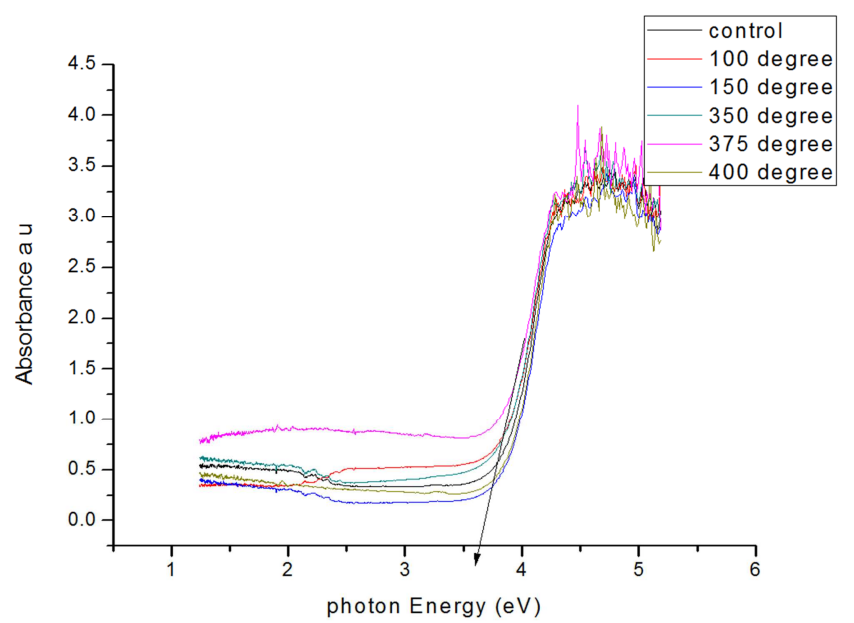

Figure 6. Plot of absorption vs. photon energy in electron volts (eV) at $375^{\circ} \mathrm{C}$.

\section{Conclusion}

It has also been demonstrated in the work that gradual thermal annealing, in a controlled manner revealed a more stable and efficient control in tuning the $\mathrm{TiO}_{2}$ :AgNPs thin film. The results can be used to develop a guideline for improving the design and fabrication of organic solar cells. The result obtained could lead to improvement in performance and stability of solar cells. The research was chosen to study the effect of thermal annealing on the optical properties of $\mathrm{TiO}_{2}$ : AgNPs materials a precursor towards an improved dye synthesized solar cells (DSSC) and organic solar cells fabrication.

\section{Conflict of Interests}

The authors declare that there is no conflict of interests regarding the publication of this article.

\section{Acknowledgements}

This research was a self -sponsored project. The authors appreciation is extended to technologist at Materials science and Engineering Laboratory Malete-Ilorin, Nigeria for their assistance with the laboratory work.

\section{References}

[1] Atwater H. A., Polman A. (2010). Plasmonics for improved photovoltaic devices. Nat Mater 9: 205-213.

[2] Heeger A. J. (2014). Bulk hetero junction solar cells: understanding the mechanism of operation. Adv Mater 26: 1028.

[3] Hamidi M., Azadi A., Rafiei P. (2008). Hydrogel nanoparticles in drug delivery. Adv Drug Deliver Rev, 60, 1638-1649 doi: 10.1016/j.addr.2008.08.002.

[4] Lowenstam H. A. (1981). Minerals formed by organisms. Science 211, 1126-1130.

[5] Lee E. J. H., Ribeiro C., Longo E., Leite E. R. (2006). Growth kinetics of tin oxide nanocrystals in colloidal suspensions under hydrothermal conditions. J. Chem. Phys. 328, 229-235.

[6] Roy P., D. Kim D., Lee K., Spiecker E., Schmuki p. (2010). $\mathrm{TiO}_{2}$ nanotubes and their application in dye-sensitized solar cells. Nanoscale., 2, 45.

[7] Linsebigler A. L., LuG., J. T. Yates J. T. (1995). Photocatalysis on TiOn Surfaces: Principles, Mechanisms, and Selected Results. Chem. Rev. 95, 735-758.

[8] Fujishima A., Honda K. (1972). $\mathrm{TiO}_{2}$ photoelectrochemistry and photocatalysis. Nature. Vol. 238, pp 37-38.

[9] Wang X, Fujimaki M, Awazu K. (2005). "Photonic crystal structures in titanium dioxide $\left(\mathrm{TiO}_{2}\right)$ and their optimal design," Opt. Express 13, 1486-1497.

[10] M. Anpo, Catal. (1997). Photocatalysis on titanium oxide catalysts: Approaches in achieving highly efficient reactions and realizing the use of visible light, Surv. Jpn Vol. 1, Issue 2, pp 169-179.

[11] Kim H. M., KokuboT., MiyajiF., NakamuraT. (1996). JBiomed. Mater. Res. 32, 409.

[12] Mann S. (2001). Biomineralization: Principles and Concepts in Bioinorganic Materials Chemistry (Oxford Univ. Press, Oxford).

[13] Abhishek G., Sharad V., Pramod K. S., Nitin K. (2011). Formulation, Characterization and Application on Nanoparticle: A Review Der Pharmacia Sinica, 2 (2): 17-26 www.pelagiaresearchlibrary.com

[14] Saravanana P., Ganapathyb M., Charlesc A., Tamilselvana S., Jeyasekarand R., Vimalane M. (2016). Electrical properties of green synthesized $\mathrm{TiO} 2$ nanoparticles Adv. Appl. Sci. Res., 7 (3): 158-168 www.pelagiaresearchlibrary.com

[15] Sakshum K., Kushagra K., Gauravi X., Prakhar K. (2016). Plasmonic Study of Nanoparticles in Organic Photovoltic Cells: A Review. J Org Inorg Chem., 3: 1 DOI: 10.21767/2472-1123.100022.

[16] Bardaxoglou G., Rouleau C., Pelletier E. (2017). High Stability and Very Slow Dissolution of Bare and Polymer Coated Silver Nanoparticles Dispersed In River and Coastal Waters. J AquatPollutToxicol. Vol. 1 No. 2: 15. 
[17] Picconi F. F, Gottshalk F, Seeger S, Nowark B (2012). Industrial production quantities and uses of ten ingineered nanomaterials in Europe and the world. $J$ Nanopart Res 14: 111 .

[18] Echegoyen Y, Nerín C (2013) Nanoparticle release from nanosilver antimicrobial food containers. Food ChemToxicol 62: 16-22.

[19] Mackevica A, Olsson ME, Hansen SF (2017). The release of silver nanoparticles from commercial toothbrushes. $J$ Hazard Mater 322: 270-275.

[20] Matsuhisa N, Inoue D, Zalar P, Jin H, Matsuba Y, et al. (2017). Printable elastic conductors by in situ formation of silver nanoparticles from silver flakes. Nat Mater 16: 834-840.

[21] Reidy B, Haase A, Luch A, Dawson KA, Lynch I (2015) Mechanisms of silver nanoparticles release, transformation and toxicity: A critical review of current knowledge and recommendations for future studies and applications. Materials 6: 2295-2350.

[22] Huang L, Dai T, Xuan Y, Tegos GP, Hamblin MR (2011) Synergistic combination of chitosan acetate with nanoparticle silver as a topical antimicrobial: Efficacy against bacterial burn infections. Antimicrob Agents Chemother 55: 3432-3438.

[23] Le Ouay B, Stellacci F (2015). Antibacterial activity of silver nanoparticles: A surface science insight. Nano Today 10: 339354.

[24] Vasireddy R, Paul R., Krishna M. A (2012). Green Synthesis of Silver Nanoparticles and the Study of Optical Properties. Nanomater. nanotechnol., 2012, Vol. 2, Art. 8: 2012.

[25] Eric M. A (1998). Synthesis and Growth of $\mathrm{ZnO}$ Nanoparticles. J. Phys. Chem. B 102, 5566-5572. 